\title{
POTENTIAL APPLICATION OF ROSELLE EXTRACT IN FUNCTIONAL FOOD EMULSIONS
}

\author{
[Aplikasi Ekstrak Rosela sebagai Pengemulsi pada Sistem Emulsi Pangan Fungsional] \\ Nor Hayati Ibrahim ${ }^{1)^{*}}$, Tan Sook Lee ${ }^{1)}$ and M. Zul Helmi Rozaini²) \\ 1) Food Science Department, Faculty of Agrotechnology and Food Science \\ 2) Chemistry Department, Faculty of Science and Technology \\ University Malaysia Terengganu, 21030 Kuala Terengganu,Terengganu, Malaysia
}

Accepted November $14^{\text {th }} 2012$ / Approved March $15^{\text {th }} 2013$

\begin{abstract}
This research was undertaken to investigate the effect of Roselle (Hibiscus sabdariffa. $L$ ) extract on the physical properties and stability of extra virgin olive oil emulsions. Four different emulsions were prepared with methanolic Roselle extract (0.01 and 0.02\%) and 0.02\% BHT (commercial antioxidant) as well as without the extract/ antioxidant (control). The physical properties were studied in terms of $\mathrm{pH}$, droplet size distribution, microstructure, viscosity and stability towards phase separation and lipid oxidation (under accelerated oxidation at $60^{\circ} \mathrm{C}$ for 10 days). The emulsions with Roselle extract was found to exhibit lower polydispersity and more uniform droplet size as compared to control and BHT emulsions. The highest viscosity was observed for the emulsion with $0.02 \%$. The BHT emulsion was the most unstable towards phase separation after 15 days of storage at $5^{\circ} \mathrm{C}$. A protective effect of Roselle extract against lipid oxidation in the emulsions was clearly observed at $0,2,8$ and 10 days of accelerated storage $\left(\right.$ at $60^{\circ} \mathrm{C}$ ) with considerably low total oxidation values $(5.4$ to 13$)$. All emulsions showed insignificant deterioration with peroxide value $<20 \mathrm{meq} / \mathrm{kg}$ after oxidation period. This study provided important preliminary data on possibility of applying Roselle extract (which is known to content a significant amount of bioactive compounds) in producing functional food emulsions with acceptable properties and stability.
\end{abstract}

Keywords: antioxidants, emulsion, roselle extract, stability, properties

\begin{abstract}
ABSTRAK
Penelitian ini bertujuan untuk mempelajari pengaruh penambahan ekstrak Rosela terhadap sifat fisik dan stabilitas emulsi minyak zaitun. Empat macam emulsi digunakan sebagai sampel, yaitu emulsi dengan penambahan ekstrak metanol Rosela (0.01 dan 0.02\%), 0.02\% BHT (kontrol positif), dan emulsi tanpa penambahan ekstrak maupun antioksidan (kontrol negatif). Sifat-sifat fisik yang diamati adalah pH, distribusi ukuran droplet, struktur mikroskopis, viskositas, stabilitas terhadap pemisahan fase, dan oksidasi lipid (metoda akselerasi pada suhu $60^{\circ} \mathrm{C}$ selama 10 hari). Emulsi dengan ekstrak rosela menunjukkan polidispersitas yang lebih rendah dan ukuran droplet yang lebih seragam dibandingkan kontrol positif dan negatif. Viskositas tertinggi diperoleh pada emulsi dengan penambahan $0.02 \%$ ekstrak Rosela. Emulsi dengan BHT paling tidak stabil terhadap pemisahan fase setelah 15 hari pada penyimpanan $5^{\circ} \mathrm{C}$. Efek proteksi ekstrak rosela terhadap oksidasi lipid pada emulsi terlihat nyata pada hari ke $0,2,8$, dan 10 pada penyimpanan terakselerasi $\left(60^{\circ} \mathrm{C}\right)$, dengan nilai total oksidasi yang relatif rendah (5.4-13). Seluruh emulsi menunjukkan kerusakan yang signifikan dengan bilangan peroksida < 20 meq/kg diakhir perioda penyimpanan. Hasil penelitian ini merupakan data awal yang penting mengenai potensi penggunaan ekstrak rosela (yang telah diketahui mengandung banyak senyawa aktif) untuk meningkatkan karakteristik dan stabilitas sistem emulsi pangan fungsional.
\end{abstract}

Kata kunci: antioksidan, emulsi, ekstrak rosela, stabilitas, properti

\section{INTRODUCTION}

Hibiscus sabdariffa $L$. or literally known as Roselle closely resembles cranberries in flavour. The calyx is commonly used in production of jam, jellies, pickle and cordial in Malaysia due to its acidic flavour (Reap, 2010). Roselle calyxes contain high level of anthocyanin which contributes to higher antioxidant activity of Roselle than that of synthetic antioxidant such as butylated hydroxytoluene (BHT) (Ismail et al. 2008; Mohd-Esa et al. 2010). Moreover, a methanolic extract of Roselle calyx has

Paper Presented at International Conference on "Future of Food Factors", October 3-4, 2012, Jakarta, Indonesia.

${ }^{*}$ Corresponding Author:

Email : yati@umt.edu.my; Phone : +609-6683644 been reported to have higher anthocyanin content and antioxidant activities compared to an aquoues extract. The effectiveness of Roselle as antioxidant in food system such as beef frankfrukter and beef patties has also been proven previously (Chew, 2003; Tee et al. 2002). Roselle extract (RE) has been found to successfully inhibited lipid oxidation in beef pattis stored at $4^{\circ} \mathrm{C}$ for 14 days (Mohd-Esa et al. 2010). Besides, Tee et al. (2002) showed that RE incoporated into cooked refrigerated beef frankfurter have stronger antioxidant property than a-tocopherol. Based on these studies, the application shall be extended to a more complex food system such as oil-in-water emulsions. Lipid oxidation in such system has been proven to be more complicated due to occurrence of interfacial ingredients (Di Mattia et al. 2009). In formulating functional food emulsions, the use of highly unsaturated oils 
with medicinal benefits such as extra virgin olive oil (EVOO) is recently of interest. Unfortunately, lipid oxidation in EVOO emulsion seems to be signficant in spite of the presence of natural antioxidant compounds from EVOO itself (Di Mattia et al. 2009). On the other hand, synthetic antioxidant such as BHT has been proven to be very effective to overcome the problem. However, the use of synthetic antioxidants has raised many questions regarding to their toxicity effect (Maqsood and Benjakul, 2010). Previous study showed that synthetic antioxidants could promote carcino-genesis in food and longtime consumption of BHT might even result in endotoxemia which reduce liver antioxidant capacity (Engin et al. 2011). Therefore, more attentions have been given on the use of natural ingredient with antioxidant properties in parallel with the increasing demand for natural food additive (Cheng et al. 2007). In relation to this, Roselle is said as one of excellent source of natural antioxidant to be used in functional food emulsions yet no related studies are available. The objective of the present study was to determine the effect of RE on the physical properties and stability of EVOO emulsions.

\section{MATERIALS AND METHODS}

\section{Preparation of roselle extract and emulsion samples}

Roselle calyx was blended with methanol at ratio $1: 2$ and held for 2 hours at room temperature. The extract was obtained through filtration with filter paper (Whatman No. 1) and the methanol was evaporated using a rotary evaporator at $55^{\circ} \mathrm{C}$. Four different emulsions were prepared with methanolic RE (0.01 and $0.02 \%$ ) and $0.02 \%$ BHT (commercial antioxidant) as well as without the extract/antioxidant (control). The emulsions were prepared by homogenizing EVOO and adjusted citric acid $(\mathrm{pH} 5)$ containing sodium caseinate $(0.5 \%)$. Roselle extract was solubilized in the citric acid $(\mathrm{pH} \mathrm{5)}$ aqueous phase prior to homogenization. $20 \mathrm{~g}$ of EVOO was added simultaneously with carboxymethyl cellulose solution (1.25\%). Homogenization was carried out by means of a high-speed homogenizer (Yellow Line DI 25 Basic, IKA Werke $\mathrm{GmbH} \& \mathrm{Co}$, Germany) for $300 \mathrm{~s}$ on batches of $100 \mathrm{~g}$.

\section{Physical properties and stability analysis}

The $\mathrm{pH}$ value of sample was determined using a $\mathrm{pH}$ meter (Jenway 3010; Jenway Ltd, Essex, UK) equipped with an electrode (J95,924001, Jenway Ltd., Essex, UK). The droplet size was measured by a laser diffraction method in terms of surface-weighted $\left(d_{3.2}\right)$ and volume-weighted $\left(d_{4.3}\right)$ mean diameters using a particle size analyzer (Mastersizer 2000, Malvern Instruments Ltd, Worcestershire, UK) (Ibrahim et al. 2007 ; 2009). The viscosity was measured using a rotational viscometer (Rheomat RM 180, Rheometric Scientific Inc.) with the measuring probe no. 3 and the shear rate of $200 \mathrm{~Pa} \mathrm{~s}^{-1}$ (Day et al. 2007). The emulsion stability towards phase separation was evaluated under centrifugation force (3500 rpm for $30 \mathrm{~min}$ ). Centrifugation produced layers of an aqueous phase at the bottom, an emulsion phase in the middle and oil phase on top. The height of the separated layers was measured and converted to relative percentage as follows: $\%$ layers $=($ height of the separated layer/the total height of the emulsion) $\times 100 \%$ (Ibrahim et al. 2009). To determine emulsion stability towards lipid oxidation, the samples were incubated at $60^{\circ} \mathrm{C}$ in the incubator for 10 days to accelerate the lipid oxidation of emulsion. Sampling was carried out at 2 day intervals for determination of peroxide value (PV) and $p$-Anisidine value (AV) according to the standard iodometric AOAC Method 965.33 (AOAC, 2000) and the method described in Ibrahim et al. (2005), respectively. Total oxidation (Totox) value was calculated as $2 \mathrm{PV}+\mathrm{AV}$.

\section{Experimental design and data analysis}

Experiments were arranged using a one-way arrangement structure and the treatments were assigned based on a completely randomized design. A one-way ANOVA with Tukey's Multiple Comparisons statistical analysis was applied on a triplicate data in order to determine any significant differences at $a=0.05$ using a Minitab (Release 16) (Minitab Inc., USA) statistical software package.

\section{RESULTS AND DISCUSSION}

\section{Physical properties of emulsions}

Of all emulsions, emulsion with $0.02 \%$ Roselle extract $(0.02 R E)$ possessed the significant $(p<0.05)$ lowest $\mathrm{pH}$ value (Table 1). Previous researcher showed that $\mathrm{pH}$ of Roselle extract was in range of $\mathrm{pH}$ 2.30-2.38 when extracted using different kind of extraction method (Chumsri et al. 2008). Although quantity of Roselle extract incorporated in emulsion was very low (only $0.01-0.02 \%$ ) but the $\mathrm{pH}$ of Roselle extract was comparatively low or high acidic to cause a lower $\mathrm{pH}$ in the respective emulsions compared to those emulsions without the extract. According to Al-Kahtani and Hassan (1990), compound which contributes to the acidity of Roselle was natural constituents of organic acid such as malic, citric and 3-indolyl acetic acid. This contributed to lower $\mathrm{pH}$ of Roselle extract.

Table 1. pH and droplet size distribution of freshly prepared emulsions

\begin{tabular}{lccc}
\hline \multicolumn{1}{c}{ Sample } & $\mathrm{pH}$ & $\begin{array}{c}\text { Volume Weighted mean } \\
D[4,3], \mu \mathrm{m}\end{array}$ & $\mathrm{D}[50], \mu \mathrm{m}$ \\
\hline 0.02RE & $5.96^{\mathrm{c}} \pm 0.04$ & $7.16^{\mathrm{a}} \pm 1.66$ & $6.63^{\mathrm{a}} \pm 1.36$ \\
0.01RE & $6.06^{\mathrm{bc} \pm 0.06}$ & $7.09^{\mathrm{a}} \pm 0.02$ & $6.79 \mathrm{a} \pm 0.08$ \\
NAE & $6.16^{\mathrm{ab}} \pm 0.02$ & $8.01^{\mathrm{a}} \pm 0.24$ & $7.48^{\mathrm{a}} \pm 0.23$ \\
BHTE & $6.25^{\mathrm{a}} \pm 0.03$ & $8.14^{\mathrm{a}} \pm 1.40$ & $7.66^{\mathrm{a}} \pm 1.25$ \\
\hline
\end{tabular}

Data are reported as mean from three independent replications $(n=3)$ for each sample. ${ }^{a-c}$ means with different letter are significantly different $(p<0.05)$. NAE, control EVOO emulsion (without antioxidant), 0.02RE, 0.01RE and BHTE are EVOO emulsions containing $0.02 \%$ Roselle extract, $0.01 \%$ Roselle extract and Butylated hydroxytoluene, respectively

In the present investigation, homogenizer used was the high speed homogenizer. It was only capable of generating fairly low energy inputs to disrupt and mix oil and water phase, therefore, it was unable to produce small droplet size. Addition of Roselle extract to emulsion showed that there was no significant difference between control and BHT emulsion in terms of D [50] and surface and volume weighed mean $D[4,3]$ (Table 1). However, it is worth mentioning that emulsions containing 
Roselle extract had oil droplets with smaller size as recorded for volume-weighted mean, D[4.3] and average size of $50 \%$ droplet species, D[50].

Figure 1 shows that the droplet size distribution for all emulsions were bimodal. Factors that may contribute to bimodal distribution are time of homogenization process during emulsion preparation and speed of homogenizer. Homogenization time used for preparation of the studied emulsions was 6 minutes which was comparatively short. Thus, the portion of emulsion droplet in contact with the most intensive disruptive force produced by homogenizer in this short time was comparatively small represented by the first maximum whereby the droplet size was smaller than the second maximum. Meanwhile, the second maximum shows most droplet sizes of all emulsions were approximately $10 \mu \mathrm{m}$ which was in the range of droplet diameter of typical emulsion system i.e. 1-100 $\mu \mathrm{m}$ (McClement, 2004). As seen in Figure 1, all emulsions have almost the same volume of droplet with the smallest size range (the first maximum) while there were volume of droplets with the largest size range (the second maximum). Roselle extract (RE) added emulsions showed the droplet size distributions that skewed to the left indicating a smaller range of droplet size compared to Butylated hydroxytoluene emulsion (BHTE) and control emulsion (NAE). This was compatible with the average droplet sizes showed in Table 1, whereby the RE emulsions had smaller droplets. This probably due to surface activity exhibited by bioactive compounds of Roselle extract which in turn caused the droplet easily break down when agitation mechanism was applied during homogenization. Roselle extract has been reported to be rich in phenolic antioxidants which possess surface activity (Richards et al. 2002; Di Mattia et al. 2009) due to its chemical structure. Therefore, it favours the formation of small and uniform oil droplets.

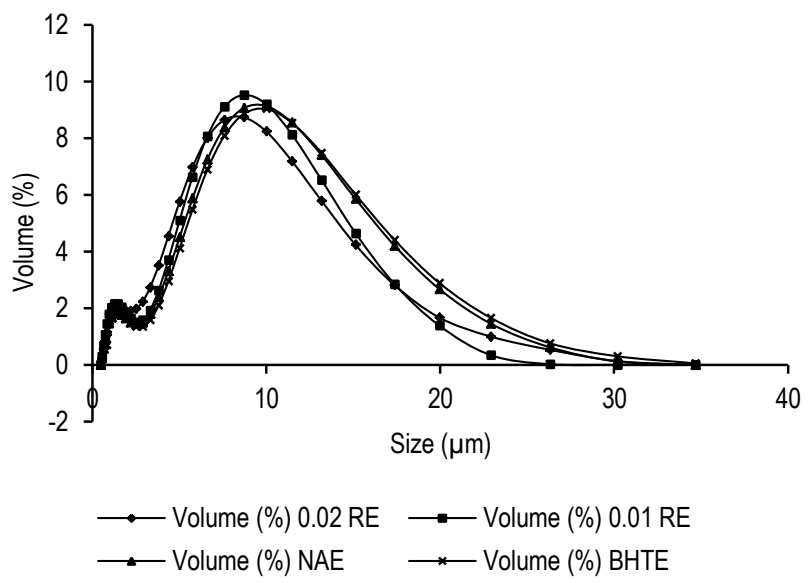

Figure 1. Droplet size distribution of emulsions. Data points are presented in average of two replications. See Table 1 for abbreviation of the samples

The microstructure of all emulsions showed no marked difference (Figure 2) which is in parallel with the insignificant difference in their droplet size distribution. Polydispersity characteristic was demonstrated in the micrograph with the existence of a mixture of droplet with different sizes. Droplet of
BHT emulsion was densely packed in smaller size, it had high tendency to aggregate together and cause flocculation as shown in deep dark background of the micrograph. According to McClement (2004), flocculation occurs when two or more droplets come together to form an aggregate in which the droplets retain their individual integrity. A few larger droplets are observable for all emulsions in the respective micrographs. This may due to the coalescence phenomenon when emulsion was exposed to higher temperature during transportation of emulsion to be analyzed. Beside, increasing kinetic energy during transportation also increased frequency of contact between droplets. Therefore, coalescence occurred and this contributed to larger oil droplets. Micrographs in Figure 2 show that 0.02 RE have more uniform size of droplet compared with NAE and BHTE due to the reason as explained before.

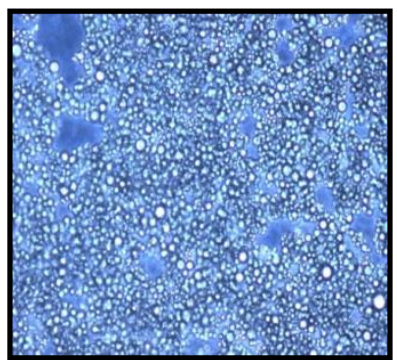

$0.02 \mathrm{RE}$

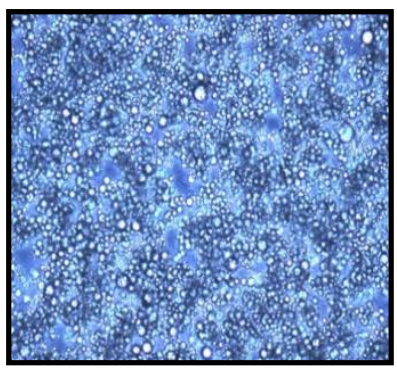

NAE

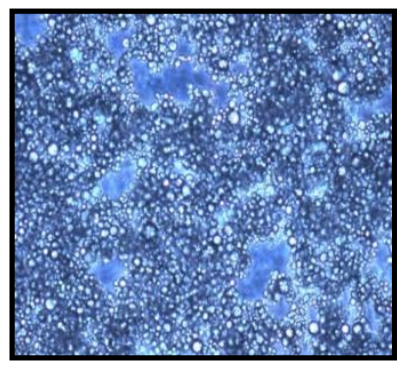

$0.01 \mathrm{RE}$

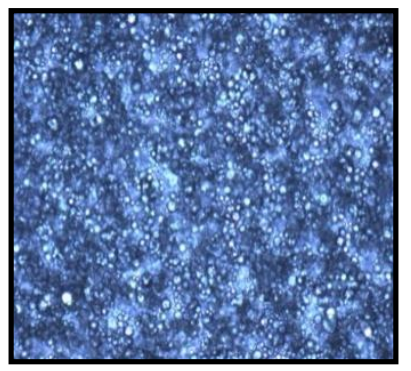

BHTE
Figure 2. Micrographs of freshly prepared emulsions with $20 \mathrm{X}$ magnifications. See Table 1 for abbreviation of the samples

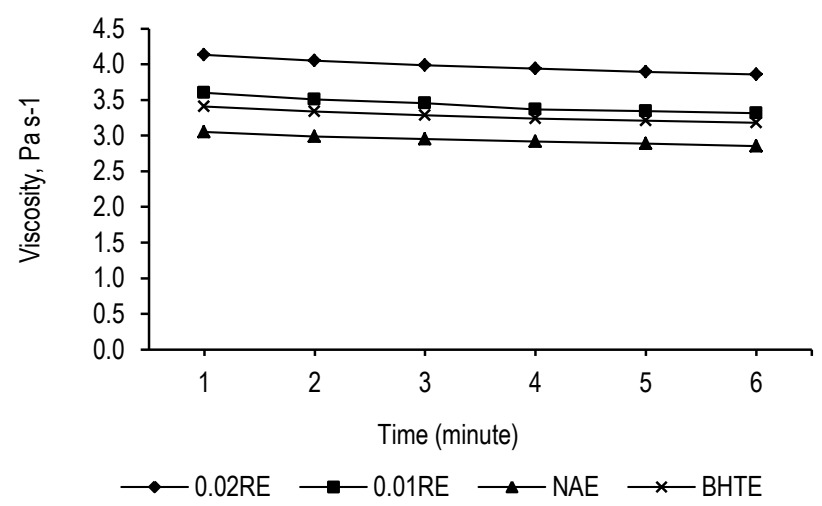

Figure 3. Viscosity of emulsions as a function of time. Data points are presented in average of three replications. See Table 1 for abbreviation of the samples

Figure 3 shows the flow of viscosity at $200 \mathrm{~s}^{-1}$ as a function of time. The viscosity flow of all emulsions showed gradual decreases with time. This is due to the aggregated droplets 
which were holding by a weak force were gradually disrupted and collapsed because of the shearing of the materials, hence decrease the resistance to flow and consequently cause the reduction of the apparent viscosity over time (McClements, 2004). Besides, when time increase, particle rotate will more align with the rotational flow of probe causing the emulsion viscosity decreased gradually. Emulsion with 0.02RE showed the highest viscosity. Roselle extract is an acidic phenolic antioxidant ( $\mathrm{pH}$ 2.30-pH 2.38) (Chumsri et al. 2008) which can contribute to the low $\mathrm{pH}$ of emulsion, causing the reduction in electrostatic repulsion in between droplet molecules, contribute to formation flocculated droplets which can increase the viscosity which was in parallel with the study of Chumsri et al. (2008).

\section{Emulsion stability towards phase separation}

For centrifugation assay, two layers were formed for all freshly prepared emulsions. There was formation of emulsion (or cream) (top layer) and aqueous (top layer) phases. This was probably due to synerisis phenomenon. However, the extent of phase separation of all emulsions was not pronounced which might be due to the presence of CMC in the emulsions (Ibrahim et al. 2009). Table 2 shows that the control emulsion exhibited the highest synerisis (lowest percentage of the emulsion phase). This may be due to the weak structure with a low viscosity in continuous phase. This led to very high droplet mobility. According to Dickinson and Leser (2007), low viscosity emulsion was more prone to creaming and synerisis due to differential creaming speeds of individual small and large droplets, making them to stick together. RE emulsion showed lower phase separation due to higher viscosity of the emulsions.

Table 2. Phase separation of emulsions after centrifugation

\begin{tabular}{lcc}
\hline \multirow{2}{*}{ Sample } & \multicolumn{2}{c}{ Emulsion Phase (\%) } \\
\cline { 2 - 3 } & $\begin{array}{c}\text { Freshly Prepared } \\
\text { Emulsions }\end{array}$ & $\begin{array}{c}\text { Stored Emulsions } \\
\left(5^{\circ} \mathrm{C}, 15 \text { Days }\right)\end{array}$ \\
\hline $0.02 \mathrm{RE}$ & $73.50 \pm 0.90$ & $65.40 \pm 3.13$ \\
0.01RE & $73.30 \pm 2.00$ & $63.20 \pm 3.18$ \\
NAE & $71.10 \pm 2.56$ & $63.40 \pm 1.15$ \\
BHTE & $73.40 \pm 0.69$ & $60.00 \pm 3.75$ \\
\hline
\end{tabular}

Data are reported as mean from three independent replications $(n=3)$ for each sample. See Table 1 for abbreviation of the samples

After 15 days of storage at $5^{\circ} \mathrm{C}$, all emulsions showed increases in phase separation. This was attributed with coalescence that continuously occurred upon storage which resulted in separation of emulsion with time until a balance condition was reached (based on density). Balance condition means that the phases were in equilibrium. When comparing all emulsions, RE emulsion showed lower phase separation after 15 day after centrifugation suggesting that Roselle extract caused higher stability to the emulsion compared to BHT.

\section{Total oxidation (Totox) value}

The Totox value combines evidence about the past history and the present state of an oil, and is used frequently in the food industry (Shahidi and Wanasundara, 2002) and it is a summation of anisidine value (AV) and twice peroxide value (PV). Figure 4 shows that the Totox value of $0.02 R E$ emulsion was lower at day 0, 2 and 8 compared to other emulsions. This indicates antioxidant activities of RE in delaying total oxidation. Data from a previous researcher who studied on palm oil quality in terms of chemical and sensory characteristics revealed that oil sample with a Totox value of 3.48 corresponded to an overall quality rating of 3.3 on a $1-5$ hedonic scale (1=very poor; $5=$ very good). Overall quality for second oil (Totox value $=8.68$ ) was 1.3 (poor) for the result obtained from the same sensory panels (Idris et al. 1992). However, according to Rosell (1986), oil samples with a Totox value above 10 was unacceptable. From the result obtained, after 6 days of incubation time, the emulsion showed an unacceptable flavour. The sharp decrease of Totox value at day 2 and 10 was due to the decrease in PV at corresponding day because Totox value was the summation of twice PV and AV at the same day. RE emulsion showed higher protective effect at the day mentioned above which is much probably due to the presence of bioactive compounds such as anthocyanins.

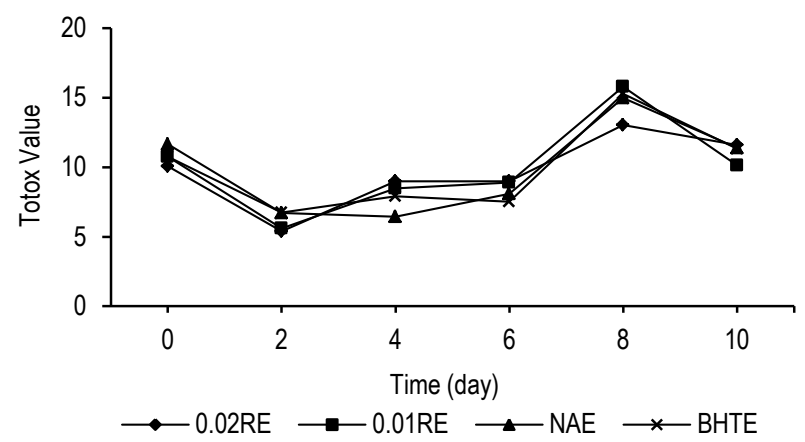

Figure 4. Total oxidation (Totox) value of emulsions within 10 days of accelerated oxidation period. Data are pointed as mean from three independent replications $(n=3)$ for each sample. See Table 1 for abbreviation of the samples

\section{CONCLUSION}

This study provided important preliminary data on possibility of applying Roselle extract (which is known to content a significant amount of bioactive compounds) in producing food emulsions with acceptable properties and stability. Moreover, one can preserve the benefit from extra virgin olive oil in the form of functional emulsion and also grant the ability of Roselle extract to form more stable emulsion upon normal storage. Further study should be done to increase amount of Roselle extract added to emulsion to increase the stability of the emulsion more significantly.

\section{ACKNOWLEDGEMENT}

This work was supported in part by Ministry of Higher Education (Malaysia) under FRGS Grant no. 59211. This work has also been realized with PSA instrumental support from Institute of Oceanography (INOS), UMT along with technical support from Mr. Mohd Azam Mat Yaakob. 


\section{REFERENCES}

Al-Kahtani H, Hassan BH. 1990. Spray drying of Roselle (Hibiscus sabdariffa L.) extract. J Food Sci 55: 1073-1076. DOI: 10.1111/j.1365-2621.1990.tb01601.x.

[AOAC] Association of Official Analytical Chemists. 2000

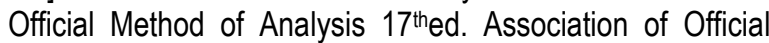
Analytical Chemists.

Cheng ZH, Zhou H, Yin J, Yu L. 2007. Electron spin resonance estimation of hydroxyl radical scavenging capacity for lipophilic antioxidants. J Agric Food Chem 55: 3325-3333. DOI: $10.1021 /$ jf0634808.

Chew LY. 2003. Application of Cocoa Shell and Roselle Seed Extracts into Beef Patties and Their Antioxidant and Free Radical Scavenging Activities. B. Sc [Thesis]. Faculty of Medicine and Health Sciences, University Putra Malaysia, Selangor, Malaysia. p 108.

Chumsri P, Sirichote A, Itharat A. 2008. Studies on the optimum conditions for the extraction and concentration of roselle (Hibiscus sabdariffa Linn.) extract. Songklanakarin J Sci Technol 30: 133-139.

Day L, Xu M, Hoobin P, Burgar I, Augustin MA. 2007. Characterisation of fish oil emulsion stabilized by sodium caseinate. Food Chem 105: 469-479. DOI: 10.1016/j. foodchem.2007.04.013.

Di Mattia CD, Sacchetti G, Mastrocola D, Pittia P. 2009. Effect of phenolic antioxidants on the dispersion state and chemical stability of olive O/W emulsions. Food Res Int 42: 1163-1170. DOI: 10.1016/.j.foodres.2009.05.017.

Dickinson E, Leser ME. 2007. Food Colloids: Self-Assembly and Material Science. RSC Publishing.

Engin $A B$, Bukan N, Kurukahvecioglu O, Memis L, Engin A 2011. Effect of butylated hydroxytoluene (E321) pretreatment versus L-arginine on liver injury after sub-lethal dose of endotoxin administration. Environ Toxicol Phar 32: 457-464. DOI: 10.1016/j.etap.2011.08.014.

Ibrahim NH, Man YBC, Tan CP, Aini IN. 2009. Droplet characterization and stability of soybean oil/palm kernel olein O/W emulsions with the presence of selected polysaccharides. Food Hydrocolloid 23: 233-243. DOl: 10.1016/.joodhyd.2008.01.004.

Ibrahim NH, Man YBC, Tan CP, Aini IN. 2005. Monitoring peroxide value in oxidized emulsions by Fourier transform infrared spectroscopy. Eur J Lipid Sci Tech 107: 886-895. DOI: $10.1002 / e j \mid t .200500241$.
Ibrahim NH, Man YBC, Tan CP, Aini IN. 2007. Stability and rheology of concentrated $\mathrm{O} / \mathrm{W}$ emulsions based on soybean oil/palm kernel olein blends. Food Res Int 40: 1051-1061. DOI: 10.1016/i.foodres.2007.05.008.

Idris NA, Abdullah A, Halim AH. 1992. Evaluation of palm oil quality: correlating sensory with chemical analyses. In: Osborn HT, Akoh CC. (Eds.). Effect of emulsifier type, droplet size, and oil concentration on lipid oxidation in structured lipid-based oil-in-water emulsions. Food Chem. 84: 451-456. DOI: 10.1016/S0308-8146(03)00270-X.

Maqsood S, Benjakul S. 2010. Comparative studies of four different phenolic compounds on in vitro antioxidative activity and the preventive effect on lipid oxidation of fish oil emulsion and fish mince. Food Chem 119: 123-132. DOI: 10.1016/j.foodchem.2009.06.004.

Ismail A, Ikram EHK, Nazri HSM. 2008. Roselle (Hibiscus sabdariffa L.) Seeds-nutritional composition, protein quality and health benefits. Food 2: 16 .

McClements DJ. 2004. Food emulsions: Principle, practice, and techniques. $2^{\text {nd }}$ ed. New York: CRC Press LLC.

Mohd-Esa, Hern FS, Ismail A, Yee CL. 2010. Antioxidant activity in different parts of Roselle (Hibiscus sabdariffa L.) extracts. Food Chem 122: 1055-1060. DOl: 10.1016/j. foodchem.2010.03.074.

Reap A. 2010. Roselle (Hibiscus sabdariffa). Reap eastafrica organisation [Online]. Available from: http://reap-eastafrica. org/blogs.info/reap/pdf/Roselle.pdf [10 March 2011].

Richards M, Chaiyasit W, McClements DJ, Decker EA. 2002. Ability of surfactants micelles to alter the partitioning of phenolic antioxidants in oil-in-water emulsions. J Agric Food Chem 50: 1254-1259. DOI: 10.1021/jf011324p.

Rosell JB. 1986. Classical analysis of oils and fats. In: Osborn HT, Akoh CC. (Eds.). Effect of emulsifier type, droplet size, and oil concentration on lipid oxidation in structured lipidbased oil-in-water emulsions. Food Chem 84: 451-456. DOl: 10.1016/S0308-8146(03)00270-X.

Shahidi F, Wanasundara UN. 2002. Methods for Measuring Oxidative Rancidity in Fats and Oils. New York: Marcel Dekkar, Inc.

Tee PJ, Yusof S, Mohamed S. 2002. Antioxidative properties of roselle (Hibiscus sabdariffa L.) in linoleic acid model system. Nutri Food Sci 32: 17-20. DOI: 10.1108/003466502 10413951 